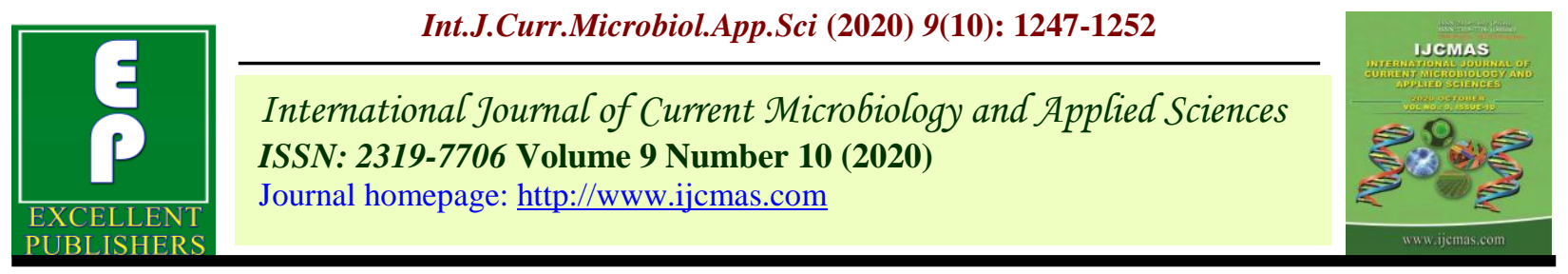

Original Research Article

https://doi.org/10.20546/ijcmas.2020.910.150

\title{
Influence by Various Zinc and Iron Treatments on Micronutrients Content and Uptake of Grain and Stover of Pearl Millet
}

\author{
C. D. Parmar ${ }^{1}$, R. R. Kharadi ${ }^{1 *}$, K. P. Bhuriya ${ }^{2}$ \\ ${ }^{1}$ Department of soil science and agricultural chemistry, B. A. College of Agriculture \\ Anand, Agricultural University, Anand, Gujarat (India)-388 110 \\ ${ }^{2}$ Main Sugarcane Research Station, Junagadh Agricultural University, \\ Kodinar, Gujarat, India \\ *Corresponding author
}

\section{A B S T R A C T}

Keywords

Pearl millet,

Zinc, Iron,

Content, Uptake

Article Info

Accepted:

10 September 2020

Available Online:

10 October 2020
The filed study was "Influence by various treatments of micronutrient of content and uptake grain and stover of pearl millet crop" was carried out during kharif season of the year 2016, at College Agronomy Farm, B. A. College of Agriculture, Anand Agricultural University, Anand. Fe and $\mathrm{Zn}$ content in grain of pearl millet was improved due to application of $\mathrm{Zn}$ and $\mathrm{Fe}$ treatments. Application of $25 \mathrm{~kg} \mathrm{ZnSO}_{4} \mathrm{ha}^{-1}+1.0 \mathrm{~kg} \mathrm{Fe} \mathrm{ha}{ }^{-1}\left(\mathrm{~T}_{8}\right)$ increased 20.2 and 19.6 percent $\mathrm{Fe}$ and $\mathrm{Zn}$ content of grain respectively over control. To Significantly higher grain uptake of Fe (118.32 $\left.\mathrm{g} \mathrm{ha}^{-1}\right)$ was found with application of 1.5 $\mathrm{kg} \mathrm{Zn} \mathrm{ha}{ }^{-1}+50 \mathrm{~kg} \mathrm{FeSO}_{4}\left(\mathrm{~T}_{5}\right) \mathrm{ha}^{-1}$ as compared to control $\left(\mathrm{T}_{1}\right)$, but it was par with the rest of treatments. Application of $25 \mathrm{~kg} \mathrm{ZnSO}_{4} \mathrm{ha}^{-1}+1.0 \mathrm{~kg} \mathrm{Fe} \mathrm{ha}^{-1}\left(\mathrm{~T}_{8}\right)$ gave higher uptake of $\mathrm{Zn}\left(64.98 \mathrm{~g} \mathrm{ha}^{-1}\right)$ as compare to $0 \mathrm{~kg} \mathrm{Zn} \mathrm{ha}^{-1}+50 \mathrm{~kg} \mathrm{FeSO}_{4} \mathrm{ha}^{-1}\left(\mathrm{~T}_{2}\right)$ and control $\left(\mathrm{T}_{1}\right)$, while rest treatments were at par with $\mathrm{T}_{8}$.Improvement in $\mathrm{Zn}$ and $\mathrm{Fe}$ content of straw was observed due to application of $\mathrm{Zn}$ and Fe. Significantly higher content of Fe $\left(70.75 \mathrm{mg} \mathrm{kg}^{-}\right.$ ${ }^{1}$ ) was found with treatment $25 \mathrm{~kg} \mathrm{ZnSO}_{4} \mathrm{ha}^{-1}+50 \mathrm{~kg} \mathrm{FeSO}_{4} \mathrm{ha}^{-1}\left(\mathrm{~T}_{10}\right)$, which was at par with all treatments barring control. Treatments $25 \mathrm{~kg} \mathrm{ZnSO}_{4} \mathrm{ha}^{-1}+0 \mathrm{~kg} \mathrm{Fe} \mathrm{ha}^{-1}\left(\mathrm{~T}_{6}\right), 25 \mathrm{~kg}$ $\mathrm{ZnSO}_{4} \mathrm{ha}^{-1}+0.5 \mathrm{~kg} \mathrm{Fe} \mathrm{ha}^{-1}\left(\mathrm{~T}_{7}\right)$ and $25 \mathrm{~kg} \mathrm{ZnSO}_{4} \mathrm{ha}^{-1}+1.5 \mathrm{~kg} \mathrm{Fe} \mathrm{ha}{ }^{-1}\left(\mathrm{~T}_{10}\right)$, produced higher content of $\mathrm{Zn}$ over the control. Treatments of zinc and iron had significant effect on iron and zinc uptake of straw. Application of $25 \mathrm{~kg} \mathrm{ZnSO}_{4} \mathrm{ha}^{-1}+50 \mathrm{~kg} \mathrm{FeSO}_{4} \mathrm{ha}^{-1}\left(\mathrm{~T}_{10}\right)$ recorded higher removal of $\mathrm{Fe}\left(463.83 \mathrm{~g} \mathrm{ha}^{-1}\right)$ and $\mathrm{Zn}\left(47.87 \mathrm{~g} \mathrm{ha}^{-1}\right)$ over control $\left(\mathrm{T}_{1}\right)$.

\section{Introduction}

Pearl millet (Pennisetum glaucum (L.) is one of the important food grain crop of India ranking fourth in average to rice, wheat and sorghum in that order. Its common name over a large part of India is bajra or bajri. Pearl millet cultivation is mainly confined to the arid and semi - arid zones prehistoric time. Gujarat ranks third in the production of pearl millet in India whereas Rajasthan tops the list and Uttar Pradesh is in second position. It is cultivated over an area of 0.39 million hectares in Gujarat. The total production is 0.79 million tones and the productivity is $2004 \mathrm{~kg} \mathrm{ha}^{-1}$ (Anon., 2016). The nutritive 
value of pearl millet is fairly high. It contains 5 per cent fat (either extract), 9.15 per cent protein, 2.7 per cent mineral matter and gives 360 calories per $100 \mathrm{~g}$ with high amount of vitamins $A$ and $B$, it imparts substantial energy to the body with easy digestibility. In addition on grain, it also supplies fair quality dry fodder in large bulk (Parmar et al., 2020).

The nutritive value of pearl millet crop is fairly high. It contains $12.4 \%$ moisture, 11.6 $\%$ protein, $5 \%$ fat, $67 \%$ carbohydrates and about $2.7 \%$ minerals. It is also rich in Vit-A, Vit-B and impart substantial energy for baby (360 calories $100 \mathrm{~g}^{-1}$ ) (Malik, 2015). Pearl millet grains are eaten cooked like rice or "chapatis" are prepared out of flour like maize or sorghum flour. Agricultural produces, lower in micronutrient content, failed to meet up its $(\mathrm{Zn})$ requirements for human nutrition (Kharadi et al., 2020). Continuous reliance on high proportion of cereals-based foods with low amount and availability of $\mathrm{Zn}$ appears to be the major reason for the widespread occurrence of the $\mathrm{Zn}$ deficiency problem in human.

Iron $(\mathrm{Fe})$ plays an important role in the plant growth. It is a cofactor for approximately 140 enzymes that catalyze unique biochemical reactions. Deficiency or low activity of iron in the plant causes chlorophyll is not produced in sufficient quantities and the leaves are pale. It helps in the formation of chlorophyll and is constituent of enzyme systems which bring about oxidation reductions in plants. Fe is essential for respiration, photosynthesis and fixation of atmospheric nitrogen by nitrogen fixing organisms. Scenario of micronutrient deficiency in north India in early eighties was different than now after four decades. Zinc deficiency remained a major problem all over country. Zinc deficiency has increased from $44 \%$ to $48 \%$ and expected to further increase up to $63 \%$ by 2025 as most of the marginal soil are showing higher response to added zinc (Parmar et al., 2020).

\section{Materials and Methods}

The filed study was planned to during kharif season of the year 2016 at the College Agronomy Farm, B. A. College of Agriculture, Anand Agricultural University, Anand. The experimental plot was prepared as per the method described by Bhuriya et al (2019). The soil of the experimental field was alkaline in reaction and soluble salt content under safe limit. It was low in organic carbon, available $\mathrm{N}$, low in available nitrogen, high in available phosphorus and available potash, while medium in available zinc and iron.Analysis dried samples (leaf and grain) were digested in di-acid mixture $\left(4 \mathrm{HNO}_{3}: 1 \mathrm{HClO}_{4}\right)$ and volume was made up with double distilled water (Jackson, 1973). The extract was filtered through Whatman filter paper No. 42. The digested extract of plant samples was used for analysis of $\mathrm{N}, \mathrm{P}$, $\mathrm{K}$, Micronutrients content and uptake was analyzed by Kjeldahl digestion method.

Total 10 treatments were included in the present investigation treatments were comprised of $\mathrm{Zn}$ and $\mathrm{Fe}$ fertilizers application through $\mathrm{ZnSO}_{4}$ and $\mathrm{FeSO}_{4}$ as well as chelated forms of $\mathrm{Zn}$ and Fe. $\mathrm{T}_{1} 0 \mathrm{~kg} \mathrm{Zn} \mathrm{ha}{ }^{-1}+0 \mathrm{~kg} \mathrm{Fe}$ $\mathrm{ha}^{-1}$ (control), $\mathrm{T}_{2} 0 \mathrm{~kg} \mathrm{Zn} \mathrm{ha}{ }^{-1}+50 \mathrm{~kg} \mathrm{FeSO}_{4}$ $\mathrm{ha}^{-1}, \mathrm{~T}_{3} 0.5 \mathrm{~kg}$ Chelated $\mathrm{Zn} \mathrm{ha}{ }^{-1}+50 \mathrm{~kg} \mathrm{FeSO}_{4}$ $\mathrm{ha}^{-1}, \mathrm{~T}_{4} 1.0 \mathrm{~kg}$ Chelated $\mathrm{Zn} \mathrm{ha}{ }^{-1}+50 \mathrm{~kg} \mathrm{FeSO}_{4}$ $\mathrm{ha}^{-1}, \mathrm{~T}_{5} 1.5 \mathrm{~kg}$ Chelated $\mathrm{Zn} \mathrm{ha}{ }^{-1}+50 \mathrm{~kg} \mathrm{FeSO}_{4}$ $\mathrm{ha}^{-1}, \mathrm{~T}_{6} 25 \mathrm{~kg} \mathrm{ZnSO}_{4} \mathrm{ha}^{-1}+0 \mathrm{~kg} \mathrm{Fe} \mathrm{ha}{ }^{-1}, \mathrm{~T}_{7} 25$ $\mathrm{kg} \mathrm{ZnSO} \mathrm{ha}^{-1}+0.5 \mathrm{~kg}$ Chelated Fe ha ${ }^{-1}, \mathrm{~T} 825$ $\mathrm{kg} \mathrm{ZnSO}_{4} \mathrm{ha}^{-1}+1.0 \mathrm{~kg}$ Chelated $\mathrm{Fe} \mathrm{ha}{ }^{-1}, \mathrm{~T}_{9} 25$ $\mathrm{kg} \mathrm{ZnSO}_{4} \mathrm{ha}^{-1}+1.5 \mathrm{~kg}$ Chelated Feha ${ }^{-1}, \mathrm{~T}_{10} 25$ $\mathrm{kg} \mathrm{ZnSO} 4 \mathrm{ha}^{-1}+50 \mathrm{~kg} \mathrm{FeSO}_{4} \mathrm{ha}^{-1}$.

$\mathrm{Zn}_{0}, \mathrm{Zn}_{0.5}, \mathrm{Zn}_{1.0}$ and $\mathrm{Zn}_{1.5}$ 0.0, 0.5, 1.0 and 1.5 kg Zn Chelated

$\mathrm{Fe}_{0}, \mathrm{Fe}_{0.5}, \mathrm{Fe}_{1.0}$ and $\mathrm{Fe}_{1.5}: 0.0,0.5,1.0$ and 1.5 kg Fe Chelated

$\mathrm{Zn}_{25}: \mathrm{ZnSO}_{4} 25 \mathrm{kgha}^{-1}$

$\mathrm{Fe}_{50}: \mathrm{FeSO}_{4} 50 \mathrm{kgha}^{-1}$ 


\section{Results and Discussion}

\section{Effect of nutrient content and uptake on grain of pear millet}

Among iron, manganese, zinc and copper content in grain, only iron and zinc content were significantly altered where in increasing trend observed with application of $\mathrm{Zn}$ and $\mathrm{Fe}$ (Table 1). Application of $\mathrm{ZnSO}_{4} @ 25 \mathrm{~kg}+$ chelated Fe@1.0kg Fe ha ${ }^{-1}\left(\mathrm{~T}_{8}\right)$ and $1.5 \mathrm{~kg} \mathrm{Zn}$ $\mathrm{ha}^{-1}+50 \mathrm{~kg} \mathrm{FeSO} 4 \mathrm{ha}^{-1}\left(\mathrm{~T}_{5}\right)$ showed significantly higher $\mathrm{Fe}$ content $\left(39.38 \mathrm{mg}^{-1}\right)$ as compare to control $\left(32.75 \mathrm{mg}^{-1}\right)$ but, it was at par with other treatments. The percent increase in $\mathrm{Fe}$ content was $20.24 \%$ due to $\mathrm{T}_{8}$ and $\mathrm{T}_{5}$ over $\mathrm{T}_{1}$.

Significantly improvement in $\mathrm{Zn}$ content in grain of pearl millet due to application of $\mathrm{Zn}$ and Fe treatments was recorded. Treatment 25 $\mathrm{kg} \mathrm{ZnSO}_{4} \mathrm{ha}^{-1}+1.0 \mathrm{~kg} \mathrm{Fe} \mathrm{ha}^{-1}\left(\mathrm{~T}_{8}\right)$, increased $19.6 \% \mathrm{Zn}$ content as compare to no application of $\mathrm{Zn}$ and $\mathrm{Fe}\left(\mathrm{T}_{1}\right)$. The $\mathrm{Zn}$ content was significantly the lowest, under no application of application of $\mathrm{Zn}$ and $\mathrm{Fe}$, but it remained at par with application of $0 \mathrm{~kg} \mathrm{Zn}$ $\mathrm{ha}^{-1}+50 \mathrm{~kg} \mathrm{FeSO}_{4} \mathrm{ha}^{-1}\left(\mathrm{~T}_{2}\right)$. Generally, all the treatments gave better performance in increasing $\mathrm{Zn}$ and $\mathrm{Fe}$ contents over the control. Increases in grain $\mathrm{Fe}$ and $\mathrm{Zn}$ concentration in cereal with an increase in Fe and $\mathrm{Zn}$ additions has been reported by several workers (Dhaliwal et al., 2009; Yilmaz et al., 1997; Seilsepour, 2006; Pahlavan Rad and Pessarakli, 2009; Cakmak et al., 2010; in wheat and Mukhi and Shukla, 1987 and Dhaliwal et al., 2010 in rice).

The significant effect of zinc and iron application was observed for $\mathrm{Fe}$ and $\mathrm{Zn}$ uptake, while non-significant effect showed for $\mathrm{Mn}$ and $\mathrm{Cu}$ uptake by grain (Table 1). Significantly higher uptake of Fe $(118.32 \mathrm{~g}$ $\mathrm{ha}^{-1}$ ) was found with application of $1.5 \mathrm{~kg}$ chelated $\mathrm{Zn} \mathrm{ha}{ }^{-1}+50 \mathrm{~kg} \mathrm{FeSO}_{4}\left(\mathrm{~T}_{5}\right) \mathrm{ha}^{-1}$ as compared to control $\left(\mathrm{T}_{1}\right)$, but it was at par with the rest of treatments. Zn uptake by pearl millet was also increased with the application $\mathrm{Zn}$ and Fe treatments (Table 1).

Table.1 Iron, manganese, zinc and copper content and uptake by grain as influenced by different treatments of zinc and iron on pear millet

\begin{tabular}{|c|c|c|c|c|c|c|c|c|c|}
\hline \multicolumn{2}{|c|}{ Treatments } & \multicolumn{4}{|c|}{ Nutrient content in grain $\left(\mathrm{mg} \mathrm{kg}^{-1}\right)$} & \multicolumn{4}{|c|}{ Nutrient uptake in grain (\%) } \\
\hline & & \multirow{2}{*}{$\begin{array}{c}\text { Fe } \\
32.75\end{array}$} & \multirow{2}{*}{$\begin{array}{c}\text { Mn } \\
8.88\end{array}$} & \multirow{2}{*}{$\begin{array}{c}\mathbf{Z n} \\
18.50\end{array}$} & \multirow{2}{*}{$\frac{\mathbf{C u}}{2.25}$} & \multirow{2}{*}{$\begin{array}{c}\text { Fe } \\
85.15\end{array}$} & \multirow{2}{*}{$\begin{array}{c}\text { Mn } \\
22.77\end{array}$} & \multirow{2}{*}{$\begin{array}{c}\mathbf{Z n} \\
47.80\end{array}$} & \multirow{2}{*}{$\begin{array}{c}\mathbf{C u} \\
5.82\end{array}$} \\
\hline $\mathbf{T}_{1}$ & $\mathbf{Z n}_{\mathbf{0}} \mathrm{Fe}_{\mathbf{0}}$ & & & & & & & & \\
\hline $\mathbf{T}_{2}$ & $\mathrm{Zn}_{\mathbf{0}} \mathrm{Fe}_{50}$ & 37.63 & 8.95 & 20.00 & 2.38 & 104.77 & 24.92 & 55.58 & 6.64 \\
\hline $\mathbf{T}_{3}$ & $\mathbf{Z n}_{0.5} \mathbf{F e}_{50}$ & 38.50 & 9.00 & 20.63 & 2.38 & 109.95 & 25.70 & 59.02 & 6.78 \\
\hline $\mathbf{T}_{4}$ & $\mathrm{Zn}_{1.0} \mathrm{Fe}_{50}$ & 38.88 & 9.13 & 21.00 & 1.88 & 114.46 & 26.90 & 61.97 & 5.53 \\
\hline $\mathbf{T}_{5}$ & $\mathbf{Z n}_{1.5} \mathbf{F e}_{50}$ & 39.38 & 9.06 & 21.63 & 2.13 & 118.32 & 27.08 & 64.83 & 6.43 \\
\hline $\mathbf{T}_{6}$ & $\mathbf{Z n}_{25} \mathbf{F e}_{0}$ & 37.38 & 9.13 & 21.00 & 2.25 & 105.72 & 25.78 & 59.40 & 6.34 \\
\hline $\mathbf{T}_{7}$ & $\mathrm{Zn}_{25} \mathrm{Fe}_{0.5}$ & 38.88 & 9.00 & 21.38 & 2.38 & 113.42 & 26.22 & 62.44 & 6.91 \\
\hline $\mathbf{T}_{8}$ & $\mathrm{Zn}_{25} \mathrm{Fe}_{1.0}$ & 39.38 & 9.06 & 22.13 & 2.25 & 115.67 & 26.63 & 64.98 & 6.61 \\
\hline $\mathbf{T}_{9}$ & $\mathrm{Zn}_{25} \mathrm{Fe}_{1.5}$ & 39.25 & 9.13 & 21.00 & 2.38 & 113.83 & 26.38 & 60.92 & 6.90 \\
\hline $\mathbf{T}_{10}$ & $\mathbf{Z n}_{25} \mathrm{Fe}_{50}$ & 38.25 & 9.19 & 20.75 & 2.25 & 118.00 & 28.32 & 64.02 & 6.95 \\
\hline & SEm \pm & 1.13 & 0.39 & 0.65 & 0.17 & 4.89 & 1.10 & 2.60 & 0.56 \\
\hline & D at $5 \%$ & 3.29 & NS & 1.88 & NS & 14.18 & NS & 7.56 & NS \\
\hline & $\mathrm{CV} \%$ & 5.96 & 8.67 & 6.24 & 14.75 & 8.89 & 8.40 & 8.66 & 17.12 \\
\hline
\end{tabular}


Table.2 Iron, manganese, zinc and copper content and uptake by stover as influenced by different treatments of zinc and iron on pearl millet

\begin{tabular}{|c|c|c|c|c|c|c|c|c|c|}
\hline \multirow{2}{*}{\multicolumn{2}{|c|}{ Treatments }} & \multicolumn{4}{|c|}{$\begin{array}{l}\text { Nutrient content in stover } \\
\left(\mathrm{mgkg}^{-1}\right)\end{array}$} & \multicolumn{4}{|c|}{$\begin{array}{l}\text { Nutrient uptake by stover } \\
\qquad\left(\mathrm{g} \mathrm{ha}^{-1}\right)\end{array}$} \\
\hline & & Fe & Mn & $\mathbf{Z n}$ & $\mathbf{C u}$ & Fe & Mn & Zn & $\mathbf{C u}$ \\
\hline $\mathbf{T}_{1}$ & $\mathbf{Z n}_{\mathbf{0}} \mathbf{F e}_{\mathbf{0}}$ & 63.50 & 12.00 & 6.50 & 2.56 & 331.51 & 62.59 & 33.92 & 13.37 \\
\hline $\mathbf{T}_{2}$ & $\mathbf{Z n}_{0} \mathbf{F e}_{50}$ & 69.88 & 13.00 & 7.13 & 2.50 & 407.66 & 75.85 & 41.61 & 14.59 \\
\hline $\mathbf{T}_{\mathbf{3}}$ & $\mathbf{Z n}_{0.5} \mathbf{F e}_{50}$ & 69.63 & 14.00 & 7.25 & 2.88 & 415.91 & 83.43 & 43.47 & 17.27 \\
\hline $\mathbf{T}_{4}$ & $\mathrm{Zn}_{1.0} \mathrm{Fe}_{50}$ & 69.13 & 13.00 & 7.38 & 2.50 & 420.20 & 78.73 & 44.86 & 15.12 \\
\hline $\mathbf{T}_{5}$ & $\mathbf{Z n}_{1.5} \mathbf{F e}_{50}$ & 69.25 & 12.25 & 7.25 & 2.50 & 428.23 & 75.77 & 44.97 & 15.51 \\
\hline $\mathbf{T}_{6}$ & $\mathbf{Z n}_{25} \mathrm{Fe}_{\mathbf{0}}$ & 67.63 & 13.63 & 7.75 & 2.25 & 401.37 & 80.92 & 46.04 & 13.36 \\
\hline $\mathbf{T}_{7}$ & $\mathrm{Zn}_{25} \mathrm{Fe}_{0.5}$ & 69.00 & 13.00 & 7.75 & 2.50 & 414.42 & 77.91 & 46.57 & 14.99 \\
\hline $\mathbf{T}_{8}$ & $\mathrm{Zn}_{25} \mathrm{Fe}_{1.0}$ & 68.50 & 12.38 & 7.50 & 2.88 & 415.25 & 74.06 & 45.60 & 17.19 \\
\hline $\mathbf{T}_{9}$ & $\mathrm{Zn}_{25} \mathrm{Fe}_{1.5}$ & 70.40 & 12.50 & 7.50 & 2.88 & 426.44 & 75.76 & 45.41 & 17.40 \\
\hline $\mathbf{T}_{10}$ & $\mathrm{Zn}_{25} \mathrm{Fe}_{50}$ & 70.75 & 12.38 & 7.75 & 2.56 & 436.83 & 77.21 & 47.87 & 15.89 \\
\hline \multicolumn{2}{|c|}{ SEm \pm} & 1.33 & 0.99 & 0.24 & 0.19 & 12.98 & 5.91 & 2.20 & 1.19 \\
\hline \multicolumn{2}{|c|}{ CD at $\overline{5} \%$} & 3.86 & NS & 0.70 & NS & 37.66 & NS & 6.39 & NS \\
\hline \multicolumn{2}{|c|}{ CV \% } & 3.87 & 15.39 & 6.50 & 14.82 & 6.33 & 15.52 & 10.01 & 15.39 \\
\hline
\end{tabular}

The $\mathrm{Zn}$ uptake ranged between 47.80 to64.98 $\mathrm{g} \mathrm{ha}^{-1}$.Application of $25 \mathrm{~kg} \mathrm{ZnSO}_{4} \mathrm{ha}^{-1}+1.0$ $\mathrm{kg}$ chelated $\mathrm{Fe} \mathrm{ha}^{-1}\left(\mathrm{~T}_{8}\right)$ gave higher uptake of $\mathrm{Zn}\left(64.98 \mathrm{~g} \mathrm{ha}^{-1}\right)$ as compare to $0 \mathrm{~kg} \mathrm{Zn} \mathrm{ha}^{-1}+$ $50 \mathrm{~kg} \mathrm{FeSO}_{4} \mathrm{ha}^{-1}\left(\mathrm{~T}_{2}\right)$ and control $\left(\mathrm{T}_{1}\right)$ while rest of the treatments were at par with $\mathrm{T}_{8}$. Regarding $\mathrm{Mn}$ and $\mathrm{Cu}$ uptake, though results were non-significant, slightly improvement observed with application $\mathrm{Zn}$ and Fe levels may be due to increase in pearl millet yield under different treatments Increased in Fe and $\mathrm{Zn}$ uptake by grain of pearl millet due to soil application of $25 \mathrm{~kg} \mathrm{ZnSO}_{4} \mathrm{ha}^{-1}$ and $50 \mathrm{~kg}$ $\mathrm{FeSO}_{4} \mathrm{ha}^{-1}$ was also reported by Jain et al., (2018).

\section{Effect of nutrient content and uptake on stover of pearl millet}

The significant variable effect of $\mathrm{Fe}$ and $\mathrm{Zn}$ application was observed for $\mathrm{Fe}$ and $\mathrm{Zn}$ contents of stover, but not for $\mathrm{Mn}$ and $\mathrm{Cu}$ content. Significantly higher content of $\mathrm{Fe}$ (70.75 $\mathrm{mg} \mathrm{kg}^{-1}$ ) was recorded with treatment $25 \mathrm{~kg} \mathrm{ZnSO} \mathrm{ha}^{-1}+50 \mathrm{~kg} \mathrm{FeSO}_{4} \mathrm{ha}^{-1}\left(\mathrm{~T}_{10}\right)$, which was at par with all treatment barring $\left(\mathrm{T}_{1}\right)$ control in (Table 2). Regarding $\mathrm{Zn}$ content, improvement was observed due to application of $\mathrm{Zn}$ and Fe. It was found in ranges from 6.50 to $7.75 \mathrm{mg} \mathrm{kg}^{-1}$ in different treatments. Significantly higher content of $\mathrm{Zn}$ found under application of $25 \mathrm{~kg} \mathrm{ZnSO}_{4} \mathrm{ha}^{-1}$ $+0 \mathrm{~kg} \mathrm{Fe} \mathrm{ha}{ }^{-1}\left(\mathrm{~T}_{6}\right), 25 \mathrm{~kg} \mathrm{ZnSO}_{4} \mathrm{ha}^{-1}+0.5 \mathrm{~kg}$ $\mathrm{Fe} \mathrm{ha}^{-1}\left(\mathrm{~T}_{7}\right)$ and $25 \mathrm{~kg} \mathrm{ZnSO}_{4} \mathrm{ha}^{-1}+1.5 \mathrm{~kg} \mathrm{Fe}^{-1}$ ha $^{-1}\left(T_{10}\right)$ over $\left(T_{1}\right)$ control. Treatments $T_{6}, T_{7}$ and $\mathrm{T}_{10}$ resulted in 19.20 per cent increased $\mathrm{Zn}$ content over control. These findings are in line with those reported Patel et al., (2008) and Yadav et al., (2011).Similarly increased zinc concentration in straw with the zinc application in soil with below $0.60 \mathrm{mg} \mathrm{kg}^{-1}$ DTPA-Zn also reported by Dwivedi and Tiwari (1992). Soil application of $25 \mathrm{~kg}$ $\mathrm{ZnSO}_{4} \mathrm{ha}^{-1}$ and $50 \mathrm{~kg} \mathrm{FeSO} 4 \mathrm{ha}^{-1}$ significantly improved $\mathrm{Fe}$ and $\mathrm{Zn}$ uptake in straw of pearl millet (Jain et al., 2018).

The data revealed that only uptake of iron and zinc was significantly increased due to $\mathrm{Zn}$ and $\mathrm{Fe}$ treatments. Application of $25 \mathrm{~kg} \mathrm{ZnSO}_{4}$ 
$\mathrm{ha}^{-1}+50 \mathrm{~kg} \mathrm{FeSO} \mathrm{ha}^{-1}\left(\mathrm{~T}_{10}\right)$ recorded higher removal of $\mathrm{Fe}\left(436.83 \mathrm{~g} \mathrm{ha}^{-1}\right)$ and $\mathrm{Zn}(47.87 \mathrm{~g}$ $\mathrm{ha}^{-1}$ ) over control $\left(\mathrm{T}_{1}\right)$ and is being par with other treatments in (Table 2). The removal of Fe was in range of 331.51 to 436.83 and 33.92 to $47.87 \mathrm{~g} \mathrm{ha}^{-1}$ for $\mathrm{Zn}$ due to different treatments. Arya and Singh (2000) noticed that application of $25 \mathrm{~kg} \quad \mathrm{ZnSO}_{4} \quad \mathrm{ha}^{-1}$ significantly increased zinc uptake instraw of maize. Soil application of $25 \mathrm{~kg} \mathrm{ZnSO} \mathrm{Zna}^{-1}$ and $50 \mathrm{~kg} \mathrm{FeSO} \mathrm{haa}^{-1}$ significantly improved Feand $\mathrm{Zn}$ uptake by straw of pearl millet (Jain et al., 2018).No significant differences on uptake of $\mathrm{Mn}$ and $\mathrm{Cu}$ observed however, improvement in uptake was found with application of iron and zinc treatments over control $\left(T_{1}\right)$ in Table 2, may be due to increase in pearl millet yield due to different treatments.

\section{References}

Anonymous (2016-2017). Annual Progress Report, Micronutrient Research Project (ICAR), AAU, Anand.

Arya, K. C. and Singh, S. N. (2000). Effect of different levels of phosphorus and zinc on yield and nutrients uptake of maize (Zea mays) with and without irrigation! Indian J. Agron., 45, 717721.

Bhuriya, K. P., Kharadi, R. R., Dodiya, V. C and Kumbhar, M. B (2019). Effect of integrated nutrient management on HCN (Hydrocyanic acid) content of forage sorghum (Sorghum bicolor L. Moench) during summer season. International Journal of Chemical Studies, 7(6): 2007-2010

Cakmak, I. Pfeiffer, W. H. and McClafferty, B. (2010). Biofortification of durum wheat with zinc and iron. Cereal Chemistry, 87(1), 10-20.

Dhaliwal, S. S., Sadana, U. S., Khurana, M. P., Dhadli, H. S. and Manchanda, J. S. (2010). Enrichment of rice grains with zinc and iron through fertifortification. Indian Journal of Fertilizers, 6(7), 28-35.

Dhaliwal, S. S., Sadana, U. S., Manchanda, J. S. and Dhadli, H. S. (2009). Biofortification of wheat grains with zinc and iron in Typic Ustochrept soils of Punjab. Indian Journal of Fertilizers, 5(11), 13-16 and 19-20.

Dwivedi, R. and Tiwari K. C. (1992). Effect of zinc sulphate application and the cyclic incorporation of cereal straw on yields, the tissue concentration and uptake of $\mathrm{Zn}$ by crops and availability of $\mathrm{Zn}$ in soil under rice-wheat rotation. International Journal of Recycle Organic Waste Agriculture, 3, 53.

Jackson, M. L. (1973). Soil Chemical Analysis, Indian edition. Prentice Hall India Pvt. Ltd., New Delhi.

Jain Amar Kumar, Swarnima Shrivastava and Vinay Aryas (2018). Response of organic manures, zinc and iron on soil properties, yield and nutrient uptake by pearl millet crop grown in incepolsols. Int. J. Pure App. BioSci., 426-435.

Kharadi, R. R., Parmar, C. D and Bhuriya, K. P. (2020). Influence of various zinc and iron treatments on yield and yield attributes of pear millet. International Journal of Chemical Studies, 8(4): 2192-2194

Mukhi, A. K. and Shukla, U. C. (1987). Iron and zinc relationship in rice grown in submerged soils. Journal of the Indian Society of Soil Science, 35(4), 685689.

Malik, S. (2015) Pearl millet nutritional values and medicinal uses. International journal of Advances Research and Innovative Ideas in education, Pp. 2395-4396.

Pahlavan Rad, M. R., Pessarakli, M. (2009). Response of wheat plants to zinc, iron and manganese applications and uptake and concentration of zinc, iron 
and manganese in wheat grains. Communication in Soil Science and Plant Analysis, 40(7/8), 1322-1332.

Patel, K. P., Patel, A. K., Patel, A. M., Patel, K. C. and Ramani, V. P. (2008). Effect of multi-micronutrient mixture on yield and uptake of micronutrients by wheat (Triticum aestivum L.) grown on sandy loam soils of North Gujarat. Asian Journal of Soil Science, 3(1), 8487.

Parmar, C. D., Kharadi, R. R and Bhuriya, K. P. (2020).Influence of Various Zinc and Iron Treatments on Nutrient Content and Uptake of Grain and Stover of Pear Millet Crop. Int.J.Curr.Microbiol.App.Sci, $\quad$ 9(8): 3361-3365
Seilsepour, M. (2006). Study of zinc effects on quantitative and qualitative traits of winter wheat in saline soil condition. Desert Journal, 11(2), 17-23.

Yadav, G. S., Shivay, Y. S. and Kumar, D. (2011). Effect of mulching and iron nutrition on productivity, nutrient uptake and economics of aerobic rice (Oryza sativa). Indian Journal of Agronomy, 56(4), 365-372.

Yilmaz, A., Ekiz, H., Torun, B., Gultekin, I., Karanlik, S., Bagci, S. A. and Cakmak, I. (1997). Effect of different zinc application methods on grain yield and zinc concentration in wheat grown on zinc-deficient calcareous soils. Journal of Plant Nutrition, 20, 461-471.

\section{How to cite this article:}

Parmar, C. D., R. R. Kharadi, Bhuriya, K. P. 2020. Influence by Various Zinc and Iron Treatments on Micronutrients Content and Uptake of Grain and Stover of Pearl Millet. Int.J.Curr.Microbiol.App.Sci. 9(10): 1247-1252. doi: https://doi.org/10.20546/ijcmas.2020.910.150 